DOI.

https://doi.org/10.22219/fths.v3i1

Received: December 2019

Accepted: January 2020

Available online: February 2020

\title{
The Effect of Aloe vera and Glycerol Addition on Edible Film of Lesser Yam Starch (Dioscorea esculenta L. Burkill)
}

\author{
Devi Dwi Siskawardani ${ }^{1 *}$, Warkoyo ${ }^{1}$, Anggit Ayu Pradana Siwi ${ }^{1}$ \\ ${ }^{1}$ Department of Food Technology; Faculty of Agriculture Animal Science; University \\ of Muhammadiyah Malang \\ *Corresponding aurhot email: $\underline{\text { devi@umm.ac.id }}$
}

\begin{abstract}
Edible films are thin layers made from hydrocolloids, lipids, and their combinations, functioning as a barrier to mass transfer. The hydrocolloid source that commonly used for edible film is starch. Lesser yam has the potential to be developed into food packaging products. It has a high starch yield (21.4\%). The starch properties, which usually obstruct the edible film production are not resistant to high temperature, it produces a starch suspension with viscosity and ability to form a gel is not uniform, cannot stand in acidic conditions, does not resist stirring, limited solubility in water, and starch gel is easy to syneresis and brittle. This study aimed to investigate the effect of glycerol and Aloe veraconcentrations on the physical and mechanical edible film. Randomized complete block design (RCBD) factorial with two factors was adopted. The first factor was Aloe vera concentration $(0,1 \%, 0.2 \%$ and $0.3 \% \mathrm{w} / \mathrm{v})$, and the second factor wasglycerol concentration $(17.5,22.5$ and $27.5 \% \mathrm{v} / \mathrm{w})$. The parameters tested included thickness, tensile strength, elongation, solubility, transparency, and water vapor transmission rate (WVTR). The results showed an interaction between the addition of glycerol and Aloe vera to thickness, tensile strength, elongation, solubility, transparency, and WVTR. The best characteristics of edible film were produced by the addition of glycerol $17.5 \%$ and Aloe vera $0.1 \%$ with thickness $(0.08 \mathrm{~mm})$, transparency $\left(1.72 \mathrm{~mm}^{-1}\right)$, tensile strength (0.156 MPa), elongation (17.25\%), solubility (53.89\%), and WVTR (4.09g $\left.m^{-2} 24 h^{-1}\right)$.
\end{abstract}

Keywords: edible film, lesser yams, glycerol, Aloe vera

\section{INTRODUCTION}

Food packaging is important to protect food from damage. Lately, almost all food packaging materials are made on plastic. Therefore, it needs to develop food packaging materials that are biodegradable with characteristics similar to plastic. One type of packaging that is environmentally friendly (biodegradable) and the characteristics are almost like plastic is edible film. The main ingredients for forming edible films are biopolymers such as proteins, carbohydrates, and lipids (Bourtoom, 2009). Tubers that have great potential to be developed as raw material for food packaging formation is lesser yam (Dioscorea esculenta L. Burkill). According to Suhardi (2002), lesser yams has the highest yield of starch and starch flour (24.28\% and 21.4\%) compared to other tubers. 
Natural starch produces a starch suspension with viscosity and gel forming ability are inconsistent, cannot stand in acidic conditions, does not resist stirring, limited solubility in water, then starch gel easily undergoes syneresis and brittle (Jouki et al., 2013; Siskawardani, et al., 2020). Chemical modification using the cross-linking agent, Aloe vera has expanded. The monophosphate starch formation will make dispersions that have higher viscosity, and better clarity, as well stability. This is due to monophosphate group presence, which can significantly reduce the starch gelatinization temperature. The edible coating from Aloe vera gel has been used for mangoes (Dang et al., 2008), apples (Ergun and Satici, 2012), and grapes (Serrano et al., 2006).

Glycerol is used effectively as a plasticizer in hydrophilic films, such as pectin, starch, gelatin, as well as in protein-based biodegradable films formation (Araujo-Farro et al., 2010). Glycerol molecules will interfere the compactness of basic polymer materials by decreasing intermolecular interactions and increasing polymer mobility thereby improving the flexibility and extensibility of edible films (Ghasemlou et al., 2011). The purpose of this study was to determine the interaction between glycerol and Aloe vera on the physical and mechanical characteristics of edible film.

\section{MATERIAL AND METHOD}

Material

The main materials included lesser yams (Dioscorea esculenta L.Burkill) obtained from Paciran Sub district, Lamongan Regency, East Java, Indonesia with a harvest age of 9 months.

\section{Equipment}

The equipment consisted of glass plates $(20 \mathrm{~cm} \times 20 \mathrm{~cm})$, baking sheets $(20$ $\mathrm{cm} \times 20 \mathrm{~cm} \times 2 \mathrm{~cm}$ ), analytical scales, thermometers, cabinet dryer, WVTR glass, screw micrometer, texture analyzer, and spectrophotometer.

\section{Research Procedure}

This research consisted of two main step. (i) Leser yam starch production started with sorted process, peeled to remove the skin, and washed thoroughly. Then Leser yam was soaked using a saline solution to remove mucus and calcium oxalate for $2 \mathrm{~h}$, followed with washed and grated. The addition of water ratio was 4:1 of Leser yam, then filtered for separating the filtrate and pulp. The filtrate was precipitated for $24 \mathrm{~h}$, washed 3 times, then dried using a cabinet dryer for 12 $\mathrm{h}$ at $60^{\circ} \mathrm{C}$. After drying, the precipitate was blended and sieved using 80 mesh size. (ii) The edible film making, started with weighed starch $3.5 \% \mathrm{w} / \mathrm{v}$. Aloe vera addition comprised of 3 concentration ( $0,1 \%, 0.2 \%$ and $0.3 \% \mathrm{w} / \mathrm{v})$. Glycerol was measured at concentrations of $17.5 \%, 22.5 \%, 27.5 \%$ (v/ leser yam). Leser yam starch, Aloe vera and glycerol made suspension with the addition of Aquades 150 
$\mathrm{mL}$, then heated using a hot plate at $80{ }^{\circ} \mathrm{C}$ for $10 \mathrm{~min}$. The suspension heated was cooled at $30^{\circ} \mathrm{C}$, then poured onto a glass plate. The edible film solution was dried at $\pm 50^{\circ} \mathrm{C}$ for $18 \mathrm{~h}$ to $24 \mathrm{~h}$, and cooled at room temperature for $15 \mathrm{~min}$.

\section{Reserach Parameter}

The edible film ready to be analyzed thickness (micrometer), tensile strength and elongation (texture analyzer), transparency (spectrophotometer at $560 \mathrm{~nm}$ ), solubility and water vapor transmission rate (WVTR) (Siskawardani, et al., 2020; Warkoyo, et al., 2014).

\section{Research Method and Data Analysis}

The randomized complete block design factorial (RCBD) with two factors and 3 replications was adopted. First factor was Aloe vera concentration (P) that comprised of 3 levels $(0,1 \%, 0.2 \%$ and $0.3 \% \mathrm{~b} / \mathrm{v})$, while second factor was glycerol (G) which consisted of 3 levels $(17.5 \%, 22.5 \%$, and $27.5 \% \mathrm{v} / \mathrm{b}$ starch). The Analysis of Variance (ANOVA) was used and continued with the comparative test of DMRT (Duncan's Multiple Range Test) with a significance level of 5\%.

\section{RESULTS AND DISCUSSION}

\section{Thickness and Transparency of Edible Film}

There was an interaction between glycerol and Aloe vera on thickness and transparency of the edible film produced, and the thickness and transparency value can be seen in Table 1. The glycerol and Aloe vera had a significant effect on the thickness. The glycerol ability to bind water is the main factor, when glycerol concentration is higher, the water evaporation rate become lower. As the results, some water in the film solution bound by glycerol, and the edible film produced is thicker. This is in accordance with the opinion of Ahmadi et al.(2012) reported increased thickness in edible films from psyllium hydrocolloid in response to the enhancement of glycerol concentration. According to Dick et al., (2015), the films with high glycerol concentration adsorbed more moisture resulting in increased thickness because of swelling. The glycerol properties of being easily soluble in water, increasing the viscosity and water binding of solution. According to Wahyudi (2009), when heating process, there are many broken starch granules, Aloe vera addition will make the broken granules become lesser, thus producing a compact paste due to the water molecules trapped inside the starch granules. As the result, the polymers that compiler the film matrix are also greater. Compared to edible film from banana starch, the thickness value was below $0.22 \mathrm{~mm}$ (Wulansari, 2016).

The combination of glycerol and Aloe vera gave significant effect on the transparency. The increasing glycerol concentration and Aloe vera produced transparency levels was higher. Increased transparency values indicate the brightness of edible films. Transparency will be directly proportional to the 
thickness and materials concentration. When the thickness or concentration of material passed increases, so the light quantity will be more absorbed. In addition, the factors that influence transparency are the raw materials characteristics (Wiryawan, 2007). In addition, it may due to in polyethylene glycol consisted high molecular weight and low content of hydroxyl groups (Hafnimardiyanti and Armin, 2016).

\section{Elongation of Edible Film}

The addition of plasticizers is very important to solve the fragility and improve flexibility of edible film (Barreto, et al., 2003). The glycerol and Aloe vera concentrations separately gave significant effect on the edible film elongation (Table 1.). The plasticizers addition can decrease the intermolecular force of the polymer chain length, but increase the flexibility. Aloe vera addition causes a reaction among starch molecules, as the result the monophosphate starch formed. Monophosphate starch can prevent the expansion and rupture of starch granules due to heating, because it can reduce starch gelatinization temperature. Wahyudi (2009) stated that, during heating process, many starch granules were broken, Aloe vera addition resulted broken granule smaller. Thus producing a compact paste due to the presence of water molecules trapped inside starch granule, and it would increase the edible film mobility and elongation. The elongation value was upper than edible film based on banana $8.2 \%$ (Wulansari, 2016)

Table 1. Thickness, Transparency and Elongation of Edible Film

\begin{tabular}{cccc}
\hline Treatment & $\begin{array}{c}\text { Thickness } \\
(\mathrm{mm})\end{array}$ & Transparency & $\begin{array}{c}\text { Elongation } \\
(\%)\end{array}$ \\
\hline P1G1 & $0.08^{\mathrm{a}}$ & $1.72^{\mathrm{a}}$ & $17.25^{\mathrm{ab}}$ \\
P1G2 & $0.09^{\mathrm{b}}$ & $1.74^{\mathrm{a}}$ & $15.55^{\mathrm{ab}}$ \\
P1G3 & $0.11^{\mathrm{c}}$ & $1.80^{\mathrm{b}}$ & $8.6^{\mathrm{a}}$ \\
P2G1 & $0.12^{\mathrm{d}}$ & $2.13^{\mathrm{c}}$ & $50.85^{\mathrm{c}}$ \\
P2G2 & $0.13^{\mathrm{e}}$ & $2.19^{\mathrm{d}}$ & $25.09^{\mathrm{b}}$ \\
P2G3 & $0.14^{\mathrm{f}}$ & $2.23^{\mathrm{d}}$ & $22.69^{\mathrm{b}}$ \\
P3G1 & $0.17^{\mathrm{g}}$ & $2.31^{\mathrm{e}}$ & $3.12^{\mathrm{a}}$ \\
P3G2 & $0.18^{\mathrm{h}}$ & $2.37^{\mathrm{f}}$ & $4.11^{\mathrm{a}}$ \\
P3G3 & $0.20^{\mathrm{i}}$ & $2.38^{\mathrm{f}}$ & $6.6^{\mathrm{a}}$ \\
\hline
\end{tabular}

The numbers followed by the same letter in each column shows insignificant differences according to Duncan's test a $5 \%$.

\section{Solubility and Tensile Strength of Edible Film}

There was an interaction between glycerol and Aloe vera on the solubility and tensile strength of edible film (Table 2.). The solubility values (28.15\%$56.65 \%$ ), were very higher from previous research (17.18\%) (Krisna, 2011). The solubility value had positive correlation to the glycerol and Aloe vera concentrations. The glycerol diminishes interactions between biopolymer 
molecules, in result increasing solubility because of its hydrophilic nature (Dick et al., 2015). Solubility become higher as the hydrophilic component of edible film, as the result water absorbed increased (Mehyar and Han, 2004; Hafnimardiyanti and Armin, 2016). In addition, the increasing number of hydroxyl groups affect to the enhancing water level is getting easier and faster into the polymer matrix and creates more mobile area with greater interchain distances (Dick, et al., 2015; Saibuatong and Phisalapong, 2010). Based on Guiterrez and Alvarez, (2016) the edible film with high solubility, it was perfect to applied in candy because it's easy to melt in mouth.

The tensile strength had positive correlation with increasing concentration of glycerol and Aloe vera. This result was consistent to the edible film based on modified arrowroot starch (Hafnimardiyanti and Armin, 2016). This is caused Aloe vera ability to bind with fibril tissue, therefore it able to increase the tensile strength (Saibuatong and Phisalapong, 2010; Miranda et al., 2018). In accordance to Park, et al., (1995) and Siskawardani, et al., (2020) reported that the addition of glycerol reduced the force among molecules through polysaccharides chain, so that the edible film structure become finer and more flexible. Glycerol is able to enter into the polymer chain, it will disrupt the starch compactness, reduce the intermolecular interactions and increase polymer mobility, so the film becomes elastic, but tensile strength become stronger (Warkoyo, et al., 2014).

Table 2. WVTR, Solubility, and Tensile Strength of Edible Film

\begin{tabular}{cccc}
\hline Treatment & WVTR & $\begin{array}{c}\text { Solubility } \\
(\%)\end{array}$ & $\begin{array}{c}\text { Tensile } \\
\text { Strength }(\mathrm{MPa})\end{array}$ \\
\hline P1G1 & $4.09^{\mathrm{e}}$ & $53.89^{\mathrm{ef}}$ & $0.156^{\mathrm{a}}$ \\
P1G2 & $3.85^{\mathrm{de}}$ & $54.93^{\mathrm{f}}$ & $0.237^{\mathrm{b}}$ \\
P1G3 & $3.71^{\mathrm{d}}$ & $56.65^{\mathrm{f}}$ & $0.353^{\mathrm{c}}$ \\
P2G1 & $3.40^{\mathrm{c}}$ & $41.03^{\mathrm{d}}$ & $0.555^{\mathrm{d}}$ \\
P2G2 & $3.26^{\mathrm{c}}$ & $46.43^{\mathrm{e}}$ & $0.722^{\mathrm{e}}$ \\
P2G3 & $2.98^{\mathrm{b}}$ & $49.20^{\mathrm{e}}$ & $0.875^{\mathrm{f}}$ \\
P3G1 & $2.92^{\mathrm{b}}$ & $28.15^{\mathrm{a}}$ & $1.114^{\mathrm{g}}$ \\
P3G2 & $2.88^{\mathrm{b}}$ & $31.48^{\mathrm{b}}$ & $1.376^{\mathrm{h}}$ \\
P3G3 & $2.61^{\mathrm{a}}$ & $53.89^{\mathrm{ef}}$ & $1.522^{\mathrm{i}}$ \\
\hline
\end{tabular}

The numbers followed by the same letter in each column shows insignificant differences according to Duncan's test a 5\%.

\section{WVTR of Edible Film}

There was an interaction between glycerol and Aloe vera significantly on WVTR edible films produced. The glycerol and Aloe vera interaction significantly affected edible film WVTR (Table 2.). Enhancement of glycerol and Aloe vera 
concentration produce transmission of water vapor become lower. In accordance to the Pinzon et al., (2018) the presence of Aloe vera reduced the hydrophilic groups availability in starch and decreased the WVTR by a crosslinking effect with the starch molecules. The height of water vapor transmission rate indicates the component that can pass through the edible film also greater. Conversely, if the WVTR value gets lower then the ability of edible film in order to resist water evaporation will be lower. In addition it's related to the high water content of Aloe vera $98.6 \%$ (Monzon-Ortega et al., 2018). Glycerol also contributed, due to has hydrophilic which add polar properties in the film that increase intermolecular distance. Therefore internal hydrogen bonds and intermolecular stresses of edible film matrix decreased, and the distance caused moisture to penetrate and enhanched permeability (Yuliastiani et al., 2020).

\section{CONCLUSION}

It can be concluded that there is significantly interaction between concentration of glycerol and Aloe vera on thickness, transparency, solubility, tensile strength, elongation and water vapor transmission rate (WVTR) of edible starch. The best treatment is G1S1 (17.5\% glycerol and 0.1\% Aloe vera) with thickness $(0.08 \mathrm{~mm})$, transparency $(1.72 \mathrm{~A} 546 / \mathrm{mm})$, solubility $(53.89 \%)$, tensile strength (0.156 MPa), elongation (17.25\%) and WVTR $\left(4.09 \mathrm{~g} \mathrm{~m}^{-2} 24 \mathrm{~h}^{-1}\right)$.

\section{REFERENCES}

Ahmadi, R.,Kalbasi-Ashtari, A.,Oromiehie, A.,Yarmand, M-S., and Jahandideh, F. 2012. Development and characterization of a novel biodegradable edible film obtained from psyllium seed (Plantago ovate Forsk). Journal of Food Engineering, 109:745-751.

Araujo-Farro, P.C., Podadera, G.,Sobral, P.J.A., and Menegalli, F.C. 2010. Development of films based on quinoa (Chenopodium quinoa, Willdenow) starch. Carbohydrate Polymers, 81:839-848

Barreto, P.L.M., Pires, A.T.N., and Soldi, V. Thermal degradation of edible films based on milk proteins andgelatin in inert atmosphere. Polym. Degrad. Stabil. 2003, 79: 147-152.

Bourtoom, T. 2009. Review Article Edible protein films: properties enhancement. International Food Research Journal 16: 1-9

Dang, K.T.H., Singh, Z., and Swinny, E.E. 2008. Edible coatings influence fruit ripening, quality, and aroma biosynthesis in mango fruit. Journal of Agricultural and Food Chemistry, 56 (4): 1361-1370

Dick, M., Costa, T. M. H., Gomaa, A., Subirade, M., Rios, A. de O., \& Flôres, S. H. 2015. Edible film production from chia seed mucilage: Effect of glycerol concentration on its physicochemical and mechanical properties. Carbohydrate Polymers, 130: 198-205. 
Ergun, M., and Satici, F. 2012. Use of Aloe vera gel as biopreservative for "Granny Smith" and "Red Chief" apples. The Journal of Animal and Plant Sciences, 22 (2): 363-368

Ghasemlou, M., Khodaiyan, F., Oromiehie ,A., and Yarmand, M.S. 2011. Development and characterization of a new biodegradable edible film made from kefiran, an exopolysaccharide obtained from kefir grains. Food Chemistry, 127:1496-1502.

Gutierrez, T.J., and Alvarez, K. 2016. Physico-chemichal Properties and In vitro Digestibility of Edibe Films Made from Plantation Flour with Added Aloe vera Gel. J. Functional Food, 26(2): 750-762

Hafnimardiyanti and Armin, M.I. 2016. Effect of Plasticizer on Physical and Mechanical Charateristics of Edible Film from Mocaf Flour. Der Pharmacia Lettre, 8 (19):301-308

Jouki, M., Khazaei, N., Ghasemlou, M., \& HadiNezhad, M. 2013. Effect of glycerol concentration on edible film production from cress seed carbohydrate gum. Carbohydrate Polymers, 96(1): 39-46.

Miranda, M., Pratama, Y., and Hintono, A. 2018. Karakterstik Edible Film Aloe vera dengan Emulsi Extra Virgin Olive Oil dan Kitosan. (Properties of Aloe vera Edible Film with Extra Virgin Olive Oil and Chitosan Emulsion). Agritech J., 38(4): 381-387. [in Bahasa Indonesia]

Krisna, D.,D. 2011. Pengaruh Regelatinasi dan Modifikasi Hidrotermal Terhadap Sifat Fisik pada Pembuatan Edible film dari Pati Kacang Merah (Vigna Angularis Sp. Tesis.

Mehyar, G.F dan Han, J.H. 2004. Physical and Mechanical Properties of High Amylosa Rice and Pea Starch Films as Affacted by Relative Humidity and Plasticizer. Journal of Food Science.

Monzon-Ortega, K., Figueroa, M.S., Lopez, D.G., Quijano, R.R., Medina, I.O., and Ovando, A.V. 2018. Characterization of Aloe vera chitosan composite films and their use for reducing the disease caused by fungi in papaya Maradol. J. Food Sci. Technol. 55(12): 4747-4757

Park, H.J. and M.S. Chinnan. 1995. Gas and Water Vapor Barrier Properties of Edible film From Protein and Cellulosa Materials. Journal of Food Eng. Vol 25. p.497.

Pinzon, M.I., Garcia, O.R., and Villa, C.C. 2018. The influence of Aloe Vera gel incorporation on the physicochemical and mechanical properties of Banana Starch-chitosan Edible Films. J.Sci. Food Agric. 1-8

Saibuatong, O., and Philasaphong, M. 2010. Novo Aloe vera bacterial Cellulose Composite Film from Biosynthesis. Carbohydrate Polymer, 79(2): $455-460$

Serrano, M., Valverde, J.M., Guillén, F., Castillo, S., Martínez-Romero, D., and Valero, D. 2006. Use of Aloe vera Gel coating preserves the functional properties of table grapes. Journal of Agricultural and Food Chemistry, 54 (11): 3882-3886

Siskawardani, D.D., Warkoyo, Hidayat, R., and Sukardi. 2020. Physic-mechanical properties of edible film based on taro starch (Colocasia 
esculenta L. Schoott) with glycerol addition. IOP Conf. Series: Earth and Environmental Science.458 (012039), 1-7

Suhardi, 2002. Hutan dan Kebun Sebagai Sumber Pangan Nasional. KANISIUS. Yogyakarta

Wahyudi. 2009. Karakterisasi Pati Ubi Kayu (Manihot Esculenta Crantz) Var.ietas Mentega Untuk Pembuatan Edible Film Dengan Penambahan Sodium Tripolyphosphate (Aloe vera). Teknologi Hasil Pertanian. Universitas Negeri Surakarta

Warkoyo, Rahardjo B., Marseno D.W., \& Karyadi J.N.W. 2014. Sifat fisik, mekanik, dan barrier edible film berbasis pati umbi kimpul (Xanthosoma saggittifolium) yang diinkoporasi dengan kalium sorbat. [Physical, mechanical and barrier properties of Xanthosoma saggittifolium stach based edible film incorporated with potassium sorbate]. AGRITECH, 34(1): $72-81$.

https://journal.ugm.ac.id/agritech/article/view/9525

Wiryawan, A. 2007. Kimia Analitik. Malang: Departemen Pendidikan Nasional.

Wulansari,W., 2016. Analisis Pengaruh Variasi Komposisi Pati Bonggol Pisang, Antioksidan Jahe dan Gliserol terhadap Karakteristik Edible Film. Thesis. UINMaulanaMalikIbrahim.Malang.

Yulistiani, F., Khairunisa, N., Fitriana, R. 2020. The effect of glycerol concentration and breadfruit flour mass on edible film characteristics. Journal of Physics: Conference series, 1-6 